Chapter 10

\title{
Dikes Stability Monitoring Versus Sinkholes and Subsidence, Dead Sea Region, Jordan
}

\author{
Damien Closson and Najib Abou Karaki \\ Additional information is available at the end of the chapter \\ http://dx.doi.org/10.5772/57277
}

\section{Introduction}

This chapter features how radar remote sensing can improve an embankment dam security project, from the planning level, to the feasibility study, the building phase, and the operational stage. The Dead Sea region provides a meaningful test bed owing to dozens kilometers of earthen dikes built over soft and very soft sediments affected by strong subsidence and sinkholes. The first section describes the context in which the collapses and subsidence proliferation have taken place. The attention is drawn over the Lisan Peninsula, Jordan, where two salt evaporation ponds encompassed by embankment dams have been built over its western margin. Then, the geological framework and the chronology of the most important damages are presented. Representative results obtained from radar differential interferometry techniques applied to ERS, Envisat, ALOS and Cosmo-SkyMed images are shown and described. Interferograms and ground displacement maps complement the work of the security engineers in providing the spatial extension and the dynamics of the geo-hazards they are dealing with.

\section{The Dead Sea, the sinkholes and subsidence}

The Dead Sea is sitting in a pull-apart basin of the Jordan-Dead Sea Transform fault zone. It is the lowest emerged place on Earth. Early January 2014, the water level was-427.82 m (Hydrological Service of Israel). But fifty years ago, it was around $-395 \mathrm{~m}$. The difference of $32 \mathrm{~m}$ results in the over pumping of the main tributaries, such as the Jordan river, and in the siphoning of the brine itself by the Dead Sea Works, in Israel, and the Arab Potash Company, in Jordan. The decline is constantly accelerating. It exceeds one meter per year in 2014. In the 1960s, the 
terminal lake was about 80 by $15 \mathrm{~km}$. Since then, one third of its original surface disappeared, leading to major changes in the hydrogeological setting and in the landscape. Before the 1980s, the Dead Sea was made up of two sub-basins (depth:-730 $\mathrm{m}$ and-402 $\mathrm{m}$ respectively) connected by the Lynch Strait and separated by the Lisan Peninsula (Fig. 1). Ever since, the deepest basin remains.

The salinity of the Dead Sea is ten times higher than the ocean water one. This characteristic makes it an attractive place for tourism and industrial activities. Two profitable mineral companies developed their plants over the shallow southern sub-basin from the mid-1960s to the early 1980s. Their production and benefits depend on the evaporation ponds' area. Fig. 1 shows the landscape of the southern Dead Sea in February 2000, when the expansion of the solar evaporation systems was at the maximum. One month later, SP-0B (Fig. 1; 7) was destroyed and one year later SP-0A (Fig. 1; 8) was emptied for dike repair.

Salty minerals soak the environment. For millennia, arid climatic conditions allowed salt crystals to grow up in the open air. Holocene sediments of the coastal zone are thus prone to dissolution when in contact with unsaturated water with respect to salt. Concomitantly to the Dead Sea level decline, an hydraulic gradient appeared with the surrounding water tables. In consequence, an increasing amount of groundwater has been drained into the shrinking lake to compensate for the lowering [1]. Gradually, the interface configuration and the equilibrium state between the hyper-saline surface body and the adjacent fresh groundwater body receiving recharge modified. The areas underlying the coastal aquifers formerly occupied by the Dead Sea water became flushed and occupied by fresh water. The latter became salinized due to the residuals of Dead Sea water in the aquifer matrix. Dissolution of covered salty deposits (Lisan formation) caused subsidence and collapses along the shorelines in the form of sinkholes, tens of meters in diameter and depth [2]. Each year, this process is causing more damages.

In 2014, the cumulated number of sinkholes recorded since the 1980s ranges between 3000 and 4000. They are found from some meters below the lake level up to several kilometers landward. At least since the 1960s, sinkholes appeared around the former southern basin, maximum 32 $\mathrm{km}$ away from the present-day Dead Sea shoreline (Fig. 1, 10). They underline the great fragility of the past and present coastal zones. The precise moment and location of the very first ground collapses are unknown. Eli Raz (personal communication) mentioned that, since the late 1970's, sinkholes have been known from Ein Gedi southward (Fig. 1, 1). Between 1978 and 1981, the southern basin and the Lynch Strait emerged gradually. Itamar and Reizmann [3] identified sinkholes over aerial photographs dating back to 1982 along the eastern and western margins of the just-emerged Lynch Strait (Fig. 1, 6). Abelson et al. [4] computed the first graph of the cumulated number of sinkholes over time for the western coast. The curve shows a gradual increase from the 1980s, a first inflexion occurred between 1997 and 2000, and then a drastic increase from 2004.

Retrospectively, the oldest and most damaged places are located inside an area about 15 by 25 $\mathrm{km}$, bounded by the resorts of Ein Gedi, Ein Boqeq, Al Mazra'a and the Wadi Shuqeiq delta [5] (Fig. 1, 1-4). At regional scale, from a tectonic point of view, this zone is characterized by a coalescence of faults [6], and is centered over the Lisan diapir, which is the largest salt dome 


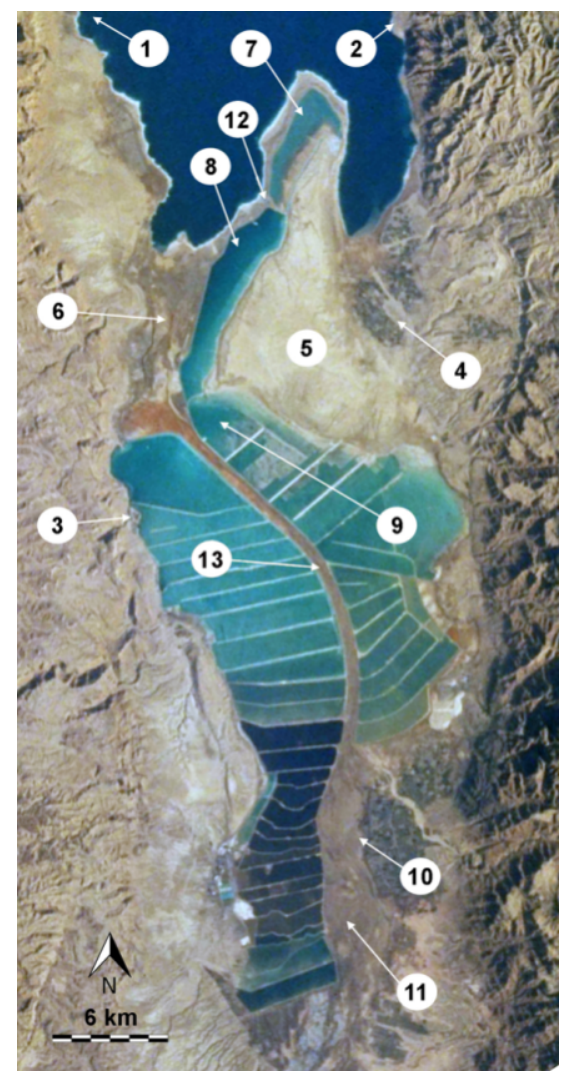

Figure 1. Dead Sea southern basin covered by salt evaporation ponds of the Arab Potash Company (East, Jordan) and Dead Sea Works (West, Israel). 1) Ein Gedi; 2) Wadi Shuqeiq delta; 3) Ein Boqeq; 4) Al Mazra'a; 5) Lisan Peninsula; 6) Lynch Strait (dried up); 7) \$38 M SP-OB; 8) \$32 M SP-0A; 9) SP-01; 10) southernmost sinkhole site; 11) Wadi Araba (braided river) flowing toward the northern Dead Sea basin; 12) Arab Potash Company brine intake station; 13) Truce line flood channel (borderline). Background: picture STS099-751-26 (Feb. 2000), Image Science and Analysis Laboratory, NASA-Johnson Space Center. "The Gateway to Astronaut Photography of Earth."

in the Dead Sea pull-apart basin [7]. Inside this polygon, two prominent sinkholes lineaments located at Ghor Al Haditha and the Lynch Strait, about 6 and $2 \mathrm{~km}$ long respectively, highlight the relationship between tectonics and ground collapses distribution. In [8], an agreement was found between their azimuths, and the one of the Jordan-Dead Sea fault system as illustrated by the focal mechanism of the April 23rd 1979 (mb=5.1) earthquake: $\mathrm{N}(20 \pm 5)^{\circ}$ E. Besides, both lineaments gather a significant part of the southern Dead Sea collapses and they are also the closest clusters to the April 23rd 1979 epicenter. The $6 \mathrm{~km}$-long alignment is the longest in the whole Dead Sea area. On the western side, a similar geometrical agreement had been found between the sinkholes distribution and the main structural directions [9]. Besides, geophysical studies [e.g. 10] have shown that sinkholes appear when a particular layer of halite, deposited 10000 years ago [11], is present several decameters below the ground level. In 2013, Ezersky 
and Frumkin [12] synthesized most of the available sub-surface and surface observations. They have shown that a large number of sinkholes sites occurred where both the edge of this layer of halite and underground discontinuities (faults or fractures acting as preferential channelways) are simultaneously present.

The $135 \mathrm{~km}$ long coastline is variously affected by sinkholes clusters. Most of them are located along the western part. In terms of damages, the eastern part-especially the industrial zone built over the Lisan Peninsula-is the most concerned. The Arab Potash Company lost a \$38 M production unit ("SP-0B") in 2000 [13] (Fig. 1, 7). Another saltpan "SP-0A" (Fig. 1, 8) is constantly threatened, necessitating lots of costly repairs. Hence, to illustrate how radar remote sensing can improve an embankment dam project, the western margin of the Lisan Peninsula where SP-0A had been built is investigated with radar/optical/thermal remote sensing techniques applied before, during, and after the construction.

\section{Geological setting of the Lisan Peninsula}

The Lisan Peninsula (Fig. 1,5) is a massive stack of late Pleistocene uplifted salt and marls layers. The Lisan Formation is characterized by laminated, biogenic carbonates, and siliciclastic sediments. Investigations revealed several transgressive depositional cycles, all terminating with massive gypsum precipitation [14].

About $120 \mathrm{~m}$ of these deposits cap the Lisan salt diapir probably formed from an anticline of an en-echelon fold train [15]. The main structure is a 9 by $6 \mathrm{~km}$ dome, N-S elongated. Two faults, striking N-S and SW-NE, bound the Lisan Peninsula in the E and NW respectively. Two secondary domes exist in the southern part [16]. Numerous lineaments related to faults directions are observed. They are represented by straight or gently curved wadies. Their direction and length vary considerably [17]. For centuries, an original salt karst developed [18] owing to the meteoric water percolation and to the base level fluctuations resulting either from the rise of the salt diapir, or the strike-slip and vertical movements related to the pull-apart basin, or the variations of the Dead Sea water level.

\subsection{Lisan Peninsula foreshore}

From the early 1970s, a wave-cut platform surrounding the Lisan Peninsula appeared progressively. Nowadays, it extends over more than three kilometers and dips very gently with a typical slope of 1: 250. Prior to the building of SP-0A and SP-0B, the surface was covered with a thin salt crust forming rigid polygonal plates typically $0.3 \mathrm{~m}$ thick and 1-2 $\mathrm{m}$ across. Small pressure ridges were apparent between many of the plates $[19,20]$. These pop-up structures resulted of the hydration of anhydrite (CaSO4) to gypsum (CaSO4:2H2O) due to undersaturated groundwater circulation in the upper horizons.

Boreholes drilled close to the brine intake station (Fig. 1, 12) of the Arab Potash Company indicated that the platform consisted of disturbed clayey silts with bands of carbonate sand and some gravel at depth [21]. Down to $13 \mathrm{~m}$, the strata were very soft. Then, they became soft, 
and firm from $16.5 \mathrm{~m}$. In general, zones of unlaminated calcareous clayey silt were interbedded with zones of gray clayey silt (calcite) thinly laminated with white silt (aragonite), typical of the Lisan formation. Laminations were mostly disturbed and discontinuous with orientations varying from horizontal, sub-horizontal to sub-vertical in places, or presented as isolated pockets within the unlaminated clayey silt and sand strata. This disturbed nature of the soil might indicate previous liquefaction of the soil layers, possibly caused by earthquake loading.

Between $17.5 \mathrm{~m}$ and $18.0 \mathrm{~m}$, a $4 \mathrm{~mm}$ vertical displacement in the horizontal laminations was observed, resulting from a shear discontinuity. Around various depths, zones of thin cemented aragonite sheets were encountered. It was presume that these zones might have higher horizontal permeabilities than the soil above and below.

Calcareous sand and gravel strata were detected at $6.5 \mathrm{~m}, 19.5 \mathrm{~m}$ and $21.5 \mathrm{~m}$. Although very silty in places, they were suspected to serve as higher permeability drainage horizons for the formation aiding consolidation. A massive halite layer was found at 17-19 $\mathrm{m}$ and 25-50 $\mathrm{m}$ depth $[19,20]$. This layer was supposed to be at the origin of the sinkholes that appeared in the early 1990s some height kilometers south of the intake station. Similar observations have been done all along the Dead Sea coast [12].

\subsection{Hydrogeological conditions before SP-0A construction}

Classification of Landsat 4 and 5 satellite images (1984-1992) collected before the setting up of SP-0A (1996-1997) allowed the delineation of local areas characterized by a specific reflectance (Fig. 2). Taking into account the context of the rapid emergence of the wave cut platform, the difference between classes is mainly related to the moisture variations in the superficial horizons. Two extreme classes $(100 \%$ water=Dead Sea, river; $0 \%$ water=former Lisan Peninsula) allow a pertinent classification of the moisture content over the platform and in the Lynch Strait.

Fig. 2 describes the Lisan foreshore as a seepage (discharge) zone. The water that circulate below the platform comes from the lowering of the Gijben-Herzberg water lens located below the Lisan Peninsula [18], and from the percolation of the confined brine in saltpan SP-01, south of the future SP-0A (Fig. 2: see remarkable seepages). A thin lens of brackish water exists below the Peninsula (Elia Salameh, personal communication). It is fed from the Mazra'a graben (Fig $1,4)$ with water coming from the Dhira basin, in connection with the Moab plateau, where annual precipitations range from 250 to $350 \mathrm{~mm}$. For centuries, the thin lens was in hydrostatic equilibrium with the Dead Sea water body which extended below the Peninsula. This setting is similar to that of islands' freshwater lens in equilibrium with the ocean water [1, 2]. Two main differences exist. The first is the angle of the fresh/saline interface. Because of the Dead Sea salinity, the angle is about ten times less than the one existing with the ocean water. The second is the physical connection with a remote recharge area (less than $6 \mathrm{~km}$ ). The temporal stability of the fresh/saline interface is attested by the development of sub-parallel caves (Fig. 3) whose floors are at the elevation of-390/-395 m. Caves are visible all along the Lisan cliff in contact with SP-0A. They extend over dozens of meters following lineaments ESE-WNW oriented. 

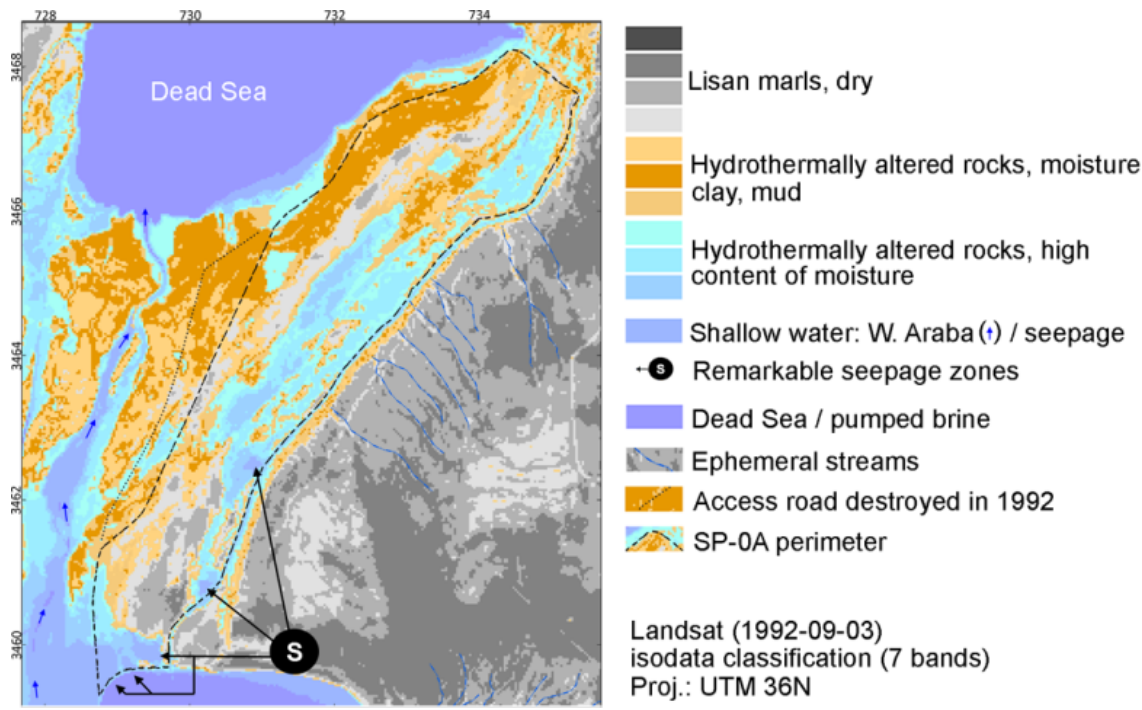

Hydrother
clay, mud

Hydrothermally altered rocks, high content of moisture

Shallow water: W. Araba $(\uparrow)$ / seepage

(s) Remarkable seepage zones

Dead Sea / pumped brine

Ephemeral streams

Access road destroyed in 1992

SP-OA perimeter

Landsat (1992-09-03)

isodata classification (7 bands)

Proj.: UTM 36N

Figure 2. Isodata classification of a Landsat image acquired prior (1992-09-03) to the setting up of SP-0A (1997-1998).

From the 1960s, the thin water lens moved down to accommodate the lowering of the base level. As a consequence, the wave-cut platform turned progressively into a discharge area. When the Lynch Strait dried up, the elevation of the lens was controlled by the level of the Dead Sea in the northern Lisan, by the elevation of Wadi Araba crossing the former Strait in the southwestern part, and by the brine level occupying the former shallow sub-basin.

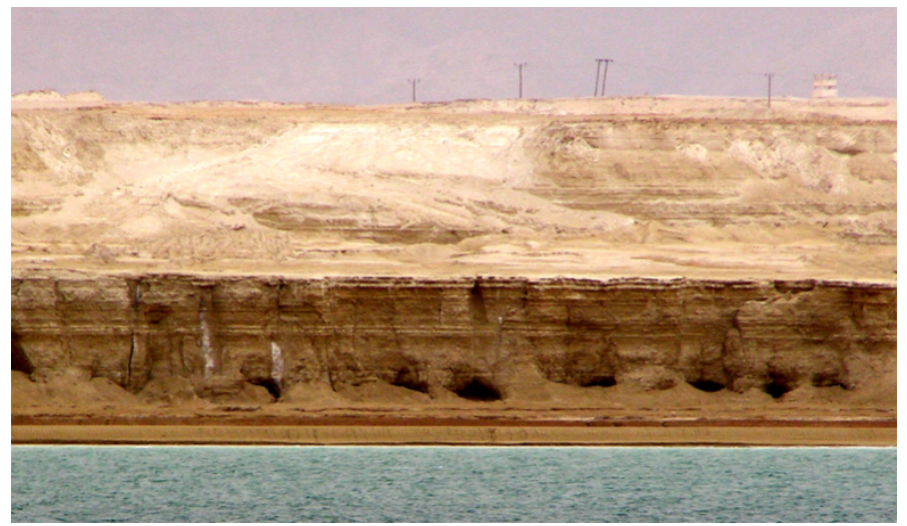

Figure 3. Picture taken from dike 18 (SP-OA) toward the east (Lisan Peninsula) and showing SP-OA filled (May $10^{\text {th }}$ 2007) and cave entrances at the place where the level of the Dead Sea was in the 1960s (around-390 m). In the background are the sub-horizontal salty marls of the Lisan Formation uplifted by a massive salt diapir more than $120 \mathrm{~m}$ below the surface (Fig. 2; grey colors). 
The easily erodible sediments of the Lynch Strait allowed a rapid entrenchment of Wadi Araba, and, consequently, a rapid drop down of the surrounding brackish water table. In 1982, the Arab Potash Company completed its solar evaporation pond system in the southern part of the Dead Sea (Fig 1;9). The peripheral dike was about $29 \mathrm{~km}$ long with its crest at-395.0 $\mathrm{m}$ and an average height of $5 \mathrm{~m}$. Reservoir SP-01-bounding the southern part of the Lisan Peninsulawas filled with Dead Sea brine in 1983. The operating brine level was-398.75 m, similar to the Dead Sea level in the early 1970s. Hence, the hydrological context was "reset" along the southern margin but not along the western and northern sides. The concentration of remarkable seepages zones (Fig. 2) in the southern part of SP-0A can be explained by the fact that the brine in SP-01 seep out through the dike and owing to numerous underground discontinuities caused by the rise of the Lisan diapir [17].

\section{Method used: DInSAR with short perpendicular baseline and SBAS}

\subsection{DInSAR}

In differential interferometry based on Synthetic Aperture Radar (SAR) imagery, the aim is to measure the differential fringe component to detect local displacements along the line of sight. After the introduction of the concept at the end of the 1980s [22] and the first demonstrations based on satellite data [23], the first dramatic examples [24] showed in the early 1990s the potential of this technique for large area measurement of small terrain deformations. Exploiting images acquired from about $700 \mathrm{~km}$, with a resolution of about 20 meters, the coherent comparison of the radar backscattered signal phase allowed the measurements of displacements in the order of some fractions of the system wavelength (some $\mathrm{cm}$ in case of the satellite SAR systems of ALOS, Envisat and ERS).

With a precise and accurate knowledge of the orbital parameters-mainly the baseline components-orbital fringes can be adequately removed. Then, topographic and differential fringe components can only be separated if one of these components is known. Hence, a topographic phase reference is needed to be subtracted from the interferogram and to generate the differential one. This topographic phase reference may be obtained either from an external DEM or from another SAR pair known as free from any differential phase component.

For the selected pairs, differential interferometric processing was applied to derive unwrapped deformation phases using the following steps (Fig. 4 [25]): raw data processing and/or direct reading of Single Look Complex (SLC) data; co-registration of SLCs to common geometry; two-pass differential interferometry processing using an oversampled ASTER GDEM as height reference, slope adaptive common band filtering, and baseline refinement; finally, phase unwrapping and geocoded displacement map.

The evolution of the research in ground motions based on DInSAR and the larger availability of data and tools allowed in the 2000s to identify the strengths and the weaknesses of this approach, its potential accuracy and the path to follow to get into an operational exploitation phase. It was clear that, to improve the reliability and accuracy of the results, to distinguish 
between real displacements and effects due to other factors like atmospheric turbulences and temporal changes of the observed objects, and to add a temporal evolution component of the observed displacement, the approach should be extended to the analysis of several images acquired over a long time period over the same area (stacking techniques).

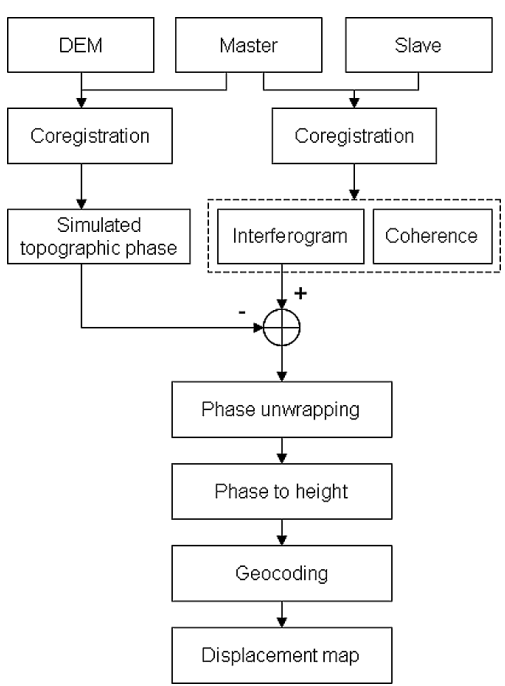

Figure 4. DInSAR flowchart [from 25]

\subsection{SBAS}

In the Dead Sea region, better results are obtained with large datasets of short baseline interferograms (see chapter "Mapping of Ground Deformations with Interferometric Stacking Techniques"). Hence, the basic idea for dikes stability monitoring is to derive deformation time series from a set of differential interferograms with "short" perpendicular baselines and time intervals keeping the level of phase gradients sufficiently low to be able to resolve the phase unwrapping stage. Using short spatial baselines optimizes the coherence and minimizes the topographic phase resulting from errors in the SRTM or ASTER GDEM height used as topographic references.

Stacking techniques have been used to get knowledge of the ground deformations from 1992 to 2010. ERS and Envisat images were stacked and processed to provide a single time series gathering all available information.

\subsection{Radar image datasets}

Several datasets have been processed to cover the period 1992-2012. The main one consisted of Envisat and ERS radar images (1992-2010): 40 Envisat ASAR images for the period 2003-2010, and 50 ERS AMI-SAR images acquired from 1992. Another set gathered 9 ALOS images 
(2007-2010). The fourth set was made up of 11 Cosmo-SkyMed images acquired from December 2011 to June 2012. Table 1 summarizes the characteristics of the pairs used to show some relevant results of the investigations.

\begin{tabular}{|c|c|c|c|c|c|c|c|c|c|}
\hline Fig. \# & Sat. & Interferom & netric pairs & T.B. & P.B. & A.H. & DS level & \multicolumn{2}{|c|}{$\begin{array}{c}\text { Dike } 18 \text { of SP-OA living } \\
\text { phases }\end{array}$} \\
\hline 5 & ERS & 1992-06-11 & 1993-08-05 & 420 & 126 & 76 & -407.4 & Planned & $\ldots-1992$ \\
\hline 6 & ERS & 1995-07-29 & 1996-07-14 & 351 & 20 & 485 & -409.6 & Feasibility study & 1993-1995 \\
\hline \multirow[b]{2}{*}{7} & \multirow[b]{2}{*}{ ERS } & 1995-12-17 & 1997-10-12 & 665 & 6 & 1485 & -410.8 & Building & 1996-1997 \\
\hline & & $1997-12-21$ & 1999-03-21 & 455 & 18 & 531 & -412.0 & $\begin{array}{l}\text { Impounding and } \\
\text { operation }\end{array}$ & 1998-2002 \\
\hline \multirow{2}{*}{8} & \multirow{2}{*}{ Envisat } & 2004-06-27 & 2004-11-14 & 140 & 37 & 249 & -417.2 & \multirow{2}{*}{$\begin{array}{l}\text { Emptying and } \\
\text { repairs }\end{array}$} & \multirow{2}{*}{ 2003-2006 } \\
\hline & & 2005-08-21 & 2006-03-19 & 210 & 16 & 571 & -418.5 & & \\
\hline 9 & ALOS & 2008-04-01 & 2008-05-17 & 46 & 41 & 1551 & -421.2 & \multirow{2}{*}{$\begin{array}{l}\text { Impounding and } \\
\text { operation }\end{array}$} & \multirow[b]{2}{*}{$2007-\ldots$} \\
\hline 10 & $\begin{array}{l}\text { Cosmo- } \\
\text { SkyMed }\end{array}$ & 2011-12-14 & 2012-05-06 & 144 & 231 & 36 & -426.0 & & \\
\hline
\end{tabular}

Table 1. Selection of interferometric pairs in the study of dike 18 living phases. T.B.=temporal baseline; P.B.=perpendicular baseline; A.H.=ambiguity height; DS level=level of the Dead Sea at the moment of the latest radar acquisition (e.g. 1993-08-05). During the period of observation, the lake level decreased by about $20 \mathrm{~m}$, or one meter per year. The slope of the Lisan foreshore where SP-OA is located is 1:250.

Figures 5 to 10 are a selection of unwrapped and wrapped interferograms having in common the small perpendicular baseline leading to high ambiguity heights. It is noteworthy to mention that the area of interest is flat, without vegetation, and human activities confined to the top of the dike.

\section{Results}

To evaluate the usefulness of radar interferometry in dike projects, it is necessary to review and to synthesize the chronology of the hazardous events that have occurred since the 1990s until present over the Lisan foreshore. Data shown in Fig. 6 to 11 have been selected to highlight specific periods of time before the construction of dike 18, during the setting up, and during operation.

\subsection{Chronology of the main events at the Arab Potash Company solar evaporation ponds system: SP-OA and SP-OB units}

Figure 5 summarized the record of hazardous events for the different living stages of SP-0A and dike 18. Elements cited below come from direct observations, satellite images analysis, 
discussions with Arab Potash engineers, and bibliography (mainly Arab Potash Company unpublished reports, proceedings, and few articles).

1. In 1982, the Arab Potash Company completed its solar evaporation system in the driedup southern Dead Sea basin. At the same period, the very first sinkholes appeared in three different places: on the eastern and western margins of the former Lynch Strait, and in Ghor Al Haditha [8].

2. During the 1980s, the yearly decline in the lake level discovered an abrasion platform around the Lisan Peninsula. Early 1990s, Arab Potash set up an expansion project consisting in the setting up of two major production units over the western and northern flanks of the Lisan: saltpans SP-0A and SP-0B, both encompassed by embankment dams over 10 meters high and numbered 18 for SP-0A, and 19-20 for SP-0B (Fig. 1; 7, 8).

3. On March 22nd 1991, a major flood occurred over a 24-hour period. It was caused by a short period of intense rainfall. The Dead Sea rose from-407.701 m on February 27 to- $407.512 \mathrm{~m}$, contrary to the long term trend of a steady decline. The dried-up Lynch Strait topography was markedly influenced by this flood. Some abandoned channels were suddenly reactivated either due to the rapid entrenchment of Wadi Araba or created during the emergence of the Lynch Strait. Subsurface water circulation was affected too.

4. In June 1991, the eruptions of Mount Pinatubo, Philippines, affected the climate of the whole planet for several years. Between 1992 and 1995, winters were particularly rainy, leading to a rise in the Dead Sea level. Winter 1991-92 was particularly remarkable; coldair temperature in the Middle East was 3 to $4^{\circ} \mathrm{C}$ below average. The volume of rain provoked an addition of about $1.510^{9} \mathrm{~m}^{3}$ freshwater to the Dead Sea and an increase of two meters in the lake level $[19,20]$.

5. In October 1992, a wide sinkhole suddenly appeared in an access road along the elevation contour-404 $\mathrm{m}$ to the west of the Lisan Peninsula. This road was routed along the intended alignment of the future SP-0A dike 18 for the extension scheme, and was to be used as access for the site investigations. Further sinkholes were discovered close to the road, and inspection of aerial photographs revealed about 70 of similar holes following what appeared to be a $1.6 \mathrm{~km}$ channel reactivated in 1991. A second sinkholes cluster was detected two kilometers south, and 400 m north of SP-01 dike 1 (Fig 1; 9). Other collapses were also identified in the flood channel, along dike 1 (Fig 1; 13) $[19,20]$. Investigations revealed that the cavities most probably developed from a massive halite layer some 15-20 $\mathrm{m}$ below the ground. At the same period, sinkholes sites spread over the western coast, between Ein Gedi and Ein Boqeq, and in cropped areas of Ghor Al Haditha. These sinkholes have modified the original shape of SP-0A. The new scheme avoided the collapsed area, thus reducing the volume of the basin.

6. Feasibility study started in 1993. At chainage 1+000, boreholes revealed artesian conditions.

7. SP-0A was built up from January 1996 to December 1997 [26]. \$32 M dike 18 (13 km by 14 m) was designed to encompass a $95 \mathrm{M} \mathrm{m}^{3}$ pond over a reactivated salt karst characterized 
by soft to very soft silty clay and massive salt rock. Several incidents happened. They were related either to large vertical settlements (2-3m) of very soft clays, or artesian conditions where sand and salt layers were present, or to the development of sinkholes.

8. In 1997, when SP-0A was still empty, a leak in dike 18 was discovered [27]. Technical studies were conducted in collaboration with local and international experts, including Sir Alexander Gibb \& Partners that designed the dike. They indicated that the problem could be either due to the formation of an artesian water basin whose high water level affected the dam or due to a sinkhole that formed back in 1996. From chainage 0+000 to $3+200$, a $110 \mathrm{~m}$ wide berm was built inside SP-0A to protect the dike.

9. Early 1998, SP-0A impounding operation started. One Landsat image acquired in February 17th 1998 showed SP-0A nearly filled. At chainage 10+600, dike 18 showed an obvious curvilinear appendix corresponding to a landfill jetty $240 \mathrm{~m}$ long, 30 to $60 \mathrm{~m}$ wide, from dike 18 toward the basin center. It was maintained throughout 1998 following the appearance of new sinkholes.

10. All Landsat images acquired in 1998 revealed important seepage zones from chainage 0+000 to around 2+000.

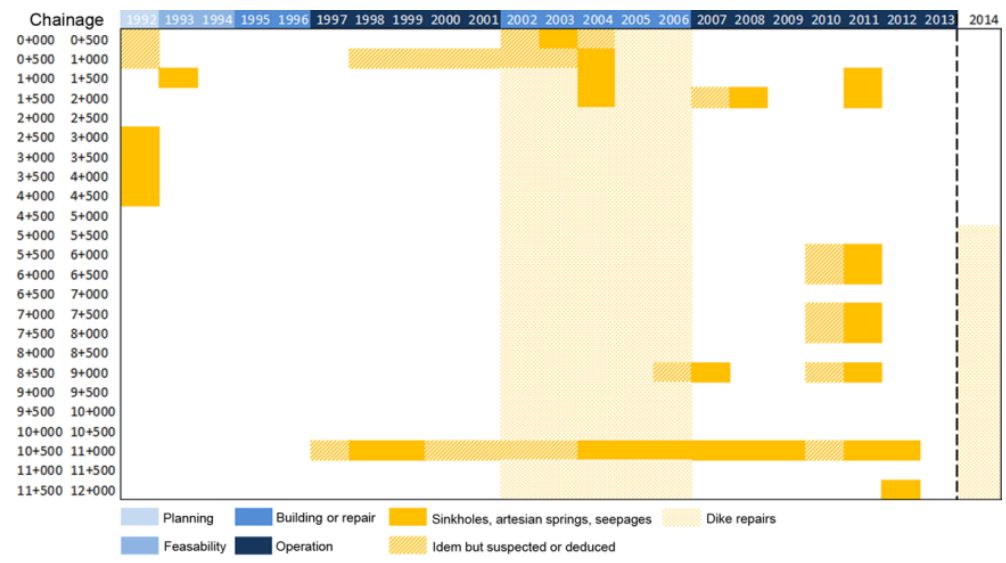

Figure 5. Hazards affecting SP-OA from planning to operation phase, distributed along dike 18 from chainage $0+000$ to $12+000$.

11. In February-March 1999, the jetty (chainage 10+600) was extended over $70 \mathrm{~m}$ to fill again a sinkhole site affecting the bottom of SP-OA.

Remarks:

- In 2004, closer inspections revealed that this structure had been made in haste. It suggested a problem caused by flow through a large channel in the vicinity of the dike. When such a problem happens, a whirlpool can appears at the surface of the pond. Once a whirlpool is 
observed, complete failure can follow rapidly (hence the need to act very quickly). It is the most serious condition that can be observed because it can enlarge until the dike is breached.

- Discussions with Arab Potash engineers confirmed that the jetty was an attempt to plug the entrance of a sinkhole site with riprap first, and then, when the plug attempt decreased the flow, with smaller materials. Since that time, this zone remained active [18]. It is the only place along the $12 \mathrm{~km}$ dike 18 where a dedicated road sign warns on the possible presence of sinkholes. Collapses are frequently observed and filled as soon as they appear.

- In May 2009, the remaining tracks of a former wide sinkhole were observed at the entrance of the jetty. No indication of seepage flow was apparent.

- Seepage is a normal phenomenon in dikes. However, it must be controlled in both velocity and quantity. If uncontrolled, it can progressively erode soil from the embankment dam or its foundation, resulting in rapid failure of the dike. Soil erosion begins at the downstream side, either in the dike proper or the foundation, and progressively works toward the reservoir. Eventually it develops a direct connection to the pond. This phenomenon of regressive erosion is known as "piping".

- Piping action can be recognized by an increased seepage flow rate, discharge of muddy or discolored water, and sinkholes on or near the dike. The above mentioned collapses are evidence of active piping in that zone from at least 1996, before the first filling of the reservoir.

12. These problems didn't stop the expansion of Arab Potash over the recently emerged wavecut platform surrounding the Lisan Peninsula. Between March 16th 1998 and December 8th 1999, a $\$ 38$ M SP-0B $\left(11 \mathrm{~km}^{2}\right)$ production unit was established and came into service early 2000. This project required the building of two dikes ( ${ }^{\circ} 19$ and $20 ; 11.6 \mathrm{~km}$ ) with a height of $14 \mathrm{~m}$. Sir Alexander Gibb \& Partners designed the dikes and the construction contract of dike 19 was awarded to the Turkish firm ATA. Pumping brine began January 4 th 2000 . The pond had a capacity of $76 \mathrm{M} \mathrm{m}^{3}$.

13. On March 22nd 2000, 4:30 PM, when the quantity of brine reached $56 \mathrm{M} \mathrm{m}^{3}$, a breach occurred in dike 19 which caused about $2.3 \mathrm{~km}$ to collapse. The brine flowed back to the Dead Sea in 30 minutes [13].

Remarks:

- In 2003, Dar Al-Handasah Harza JV, was appointed to assess the damages sustained on Dike 19. They indicated that the repair costs of the dike exceeded its net book value of an amount of $\$ 24.4 \mathrm{M}$.

- Legal proceedings ensued between the Arab Potash Company and all parties involved in the construction. On May 12th 2010, the International Centre for Settlement of Investment Disputes ordered "that the ongoing Jordanian court proceedings in relation to the Dike 19 dispute be immediately and unconditionally terminated, with no possibility to engage further judicial proceedings in Jordan or elsewhere on the substance of the dispute" [28]. 
- Between 2004-2009, in parallel to those legal proceedings, the ruins of the abandoned dike 19 and 20 exhibited an increasing number of cracks, sinkholes and decameters to hectometers landslides. In a few places bushes of Tamarix were growing, underlying the fact that unsaturated water was flowing below the pond owing to major faults playing the role of conduits [18]. Some fractures became impassable by car without using a footbridge. These damages showed an increasing instability that was consistent with observations performed elsewhere around the Dead Sea, e.g. [11]. Despite its costly setback, in 2010-2011, Arab Potash requested a "Comparative Risk Analysis for Reconstruction of a Partially Failed Dike System" [29] in which the authors propose two alternatives for the reconstruction of the failed facility.

- Cracking, settlement, and slides are the more common signs of structural failure of embankments. Seepage and structural failure are often interrelated in a complex manner. For example, uncontrolled seepage may weaken the soil and lead to a structural failure. A structural failure may shorten the seepage path and lead to a piping failure.

14. In 2000, dike 18 was seriously damaged by sinkholes [30]. It was obvious that there were subversive holes in the dike floor, since it has been filled with seawater in the year 1998. In May 2001, an increase of the artesian pressure at the bottom of the dike was noted, a fact which was considered as an indicator of the safety factor decline. This necessitated the lowering of the water level in the pond by around two meters, to raise the safety coefficient and put the pond temporarily out of operation [30].

15. A $10 \mathrm{~m}$ resolution SPOT image acquired on April 11th 2003 indicated important seepage zones coming from SP-01 toward SP-0A and affecting the bottom from chainage 0+000 to around $1+000$. Seepage extended outside SP-0A by passing below dike 18 and emerged between stations $1+000$ and $2+000$.

16. One high resolution satellite image acquired on October 20th 2004-when SP-0A was nearly emptied-showed that a berm had been built at chainage 10+600 (jetty) over a length of about $400 \mathrm{~m}$ and a distance of $150 \mathrm{~m}$. Several sinkholes affected the bottom about $300 \mathrm{~m}$ basin-ward. The same image clearly showed several other circular depressions at chainage $0+700$, about $800 \mathrm{~m}$ basin-ward. An artesian spring of very salty water was identified at chainage $1+200$, about $200 \mathrm{~m}$ from the dike, basin-ward. One sinkhole perforated the berm inside SP-0A at chainage $1+500$.

17. November 9th 2004 an agreement was signed with Sinohydro Corporation to rehabilitate Dike 18 for an amount approximating \$19.5 M [31]. The most conspicuous work consisted in the setting up of a wide seepage berm outside dike 18. Its width varied from $90 \mathrm{~m}$ in the southern part to $150 \mathrm{~m}$ in the northern part, in front of the jetty area (10+600). The project was supervised by the Dutch consultant Royal Haskoning.

18. A satellite image acquired on November 30th 2004 confirmed the observations done 40 days before. An artesian salty spring was clearly identified at chainage $1+700$. Outside dike 18 , from around chainage $1+000$ to $1+700$, important seepages of very salty brine were visible. 
19. Impounding of saltpan SP-0A started on March 14th 2006 and successfully completed its operation level on October 1st 2006. More than $87 \mathrm{M} \mathrm{m}^{3}$ of brine was pumped to reach the operation level of-393.6 m [31]. This elevation corresponded to the Dead Sea level in the mid-1930s. A Taking-Over-Certificate was issued by Royal Haskoning on December 6, 2006 and the project was considered substantially completed on November 23, 2006. The Defects Liability Period commenced on November 23rd 2006 and expired on November 22nd 2007 [32].

20. Field surveys carried out during and after repairs-in 2004, 2005, 2007, 2008, and 2009-have shown that if the rehabilitation works had actually increased the safety coefficient, so far, they failed to stop the cause of the problems. Many cracks and backfilled sinkholes were located $[5,18]$. Indeed, dike 18 is constantly threatened by cracks and sinkholes. For example, end of July 2008, from chainage 1+600 to 2+000, a $400 \mathrm{~m}$ long dike segment was enlarged to increase its safety factor. Since 1997, its width tripled.

21. Early 2011, the company launched a bid to fill underground cavities between station $6+100$ and $6+250$ (i.e. $150 \mathrm{~m}$ dike segment) with cement and thus protect a fragile part of dike 18 . The works included drilling of around 40 boreholes to an average depth of $40 \mathrm{~m}$ through the dike body and foundation soil. Thereafter, the subsurface cavities and boreholes were grouted.

22. During the 24th AFA International Technical Fertilizers Conference and Exhibition at Amman, Jordan (22-24 November 2011), Zaid Halasah, Senior Chemist at Arab Potash Company, presented two maps of sinkholes affecting SP-0A with an emphasis of the situation at station 10+600 (jetty dating back to 1998) [33]. Other sinkholes having perforated dike 18 were pointed out at chainage $5+800,7+400,8+000$. In the vicinity of the dike, sinkholes sites were found from $5+500$ to $8+800$, and at $10+600$.

23. In September 2012, during a visit taking place during the first EAGE workshop on sinkholes held in Amman, a collapse in development was located at chainage 11+500.

24. End of December 2012, a single elliptical structure having 250 by $300 \mathrm{~m}$ in diameter was identified within SP-0A from a Worldview-2 image acquired on April 2nd 2011 (chainage $1+000$ to $1+600$ ). The feature was unknown to the most aware security consultant (Royal Haskoning). Some other circular elements having a size compatible with the biggest sinkholes in the Dead Sea were also found. This "finding" raised lots of questions regarding the origin of the underlying cavity, regarding the capabilities of prediction of all models developed up to now in Jordan and in Israel about the Dead Sea sinkholes, as well as the strategies, approaches, and methods used by engineers/geophysicists the deal with such features.

25. In April 2013, a new tender announcement was launched to raise dike 18 between station $5+300$ to 11+750 (i.e. $6450 \mathrm{~m}$ of dike segment) and risk control works.

\subsection{Detection of ground displacements during planning stage}

Line of sight (LOS) motions displayed in Fig. 6 derive from a pair of ERS images acquired in June $11^{\text {th }} 1992$ and August $5^{\text {th }} 1993$, i.e. more than two years before the building of dike 18 
(1996-1997). The subsidence rate ranges from 1 to $12 \mathrm{~cm} /$ year. Wide areas are found at chainage $6+000$ to $7+000 ; 7+500$ to $8+500 ; 10+000$; and especially $11+000$ to $11+500$. Sills appear at chainage 9+000 and 7+500. Linear subsidence outside dike 18 from chainage 3+000 to 4+000 correspond the 70 sinkholes that appeared in 1992, cutting an access road that should have turned into a dike segment.

The southern part of the future SP-0A is affected by seepages coming from SP-01 or to artesian pressure in relation with the water lens below the Lisan Peninsula in hydrostatic desequilibrium with the Dead Sea level. Two hectometre-long sags are found inside Sp-OA at around chainage $0+700$, several hundreds of meters basin-ward.

In term of structural influences, the wide shallow subsidence area at chainage $9+500$ to $11+500$ (green colors) is a sag basin bounded by sub-parallel lineaments oriented N-S and SW-NE. These directions are also found in the Lisan Peninsula (dotted lines). The area located beyong chainage $11+000$ is a very active zone of subsidence. During the 1990 s its activity is attested in all interferograms computed with ERS-1/2 pairs [e.g. 34]. SSE-NNW directions are also found at chainage $5+000$. They are evidenced by the limits between brown and yellow colors. In all the distribution of lineaments inside SP-0A is in agreement with the known strike-slip derived features evidenced by geophysical prospecting in that area [35].

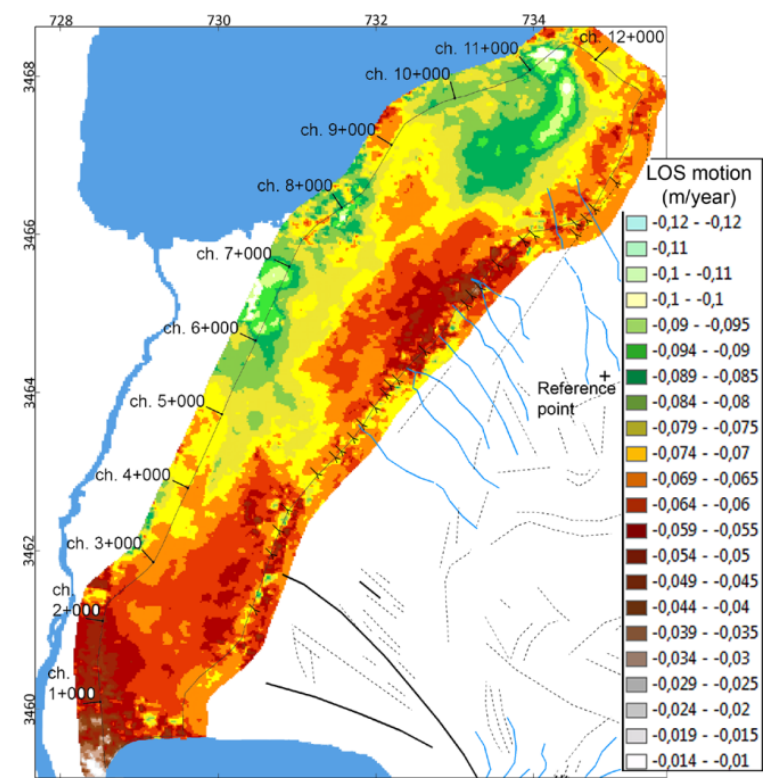

Figure 6. Line of sight motion expressed in meter/year. The period extends from June $11^{\text {th }} 1992$ to August $5^{\text {th }} 1993$ (420 days). The ERS-1 pair is characterized by a perpendicular baseline $=126 \mathrm{~m}$. Interferometric coherence (not shown) is well preserve exept along the cliff separating the Lisan Peninsula to the foreshore zone where SP-0A is located (Fig. 3). Lineaments and faults are represented as well as ephemeral streams and the cave entrances along SP-0A. The topographic phase was removed with data from ASTER GDEM. Projection UTM 36N, WGS84. 


\subsection{Detection of ground displacements during feasibility study}

Comparison between Fig. 7 and Fig. 6 indicates that the dike segments around chainage 10+000 and 11+500 are still active. The same pattern than in 1992-1993 can be found. However, the most important subsidence extends from $6+000$ to $8+5000$. This area also existed in 1992-1993 but its perimeter enlarged basin-ward. The main difference is the wide uplifted areas all along the Lisan Peninsula. This zone does not affect dike 18.

The southern part of SP-0A is affected by uplift and subsidence in a way different than in the central and northern parts. This is most probably due to seepages coming from SP-01.
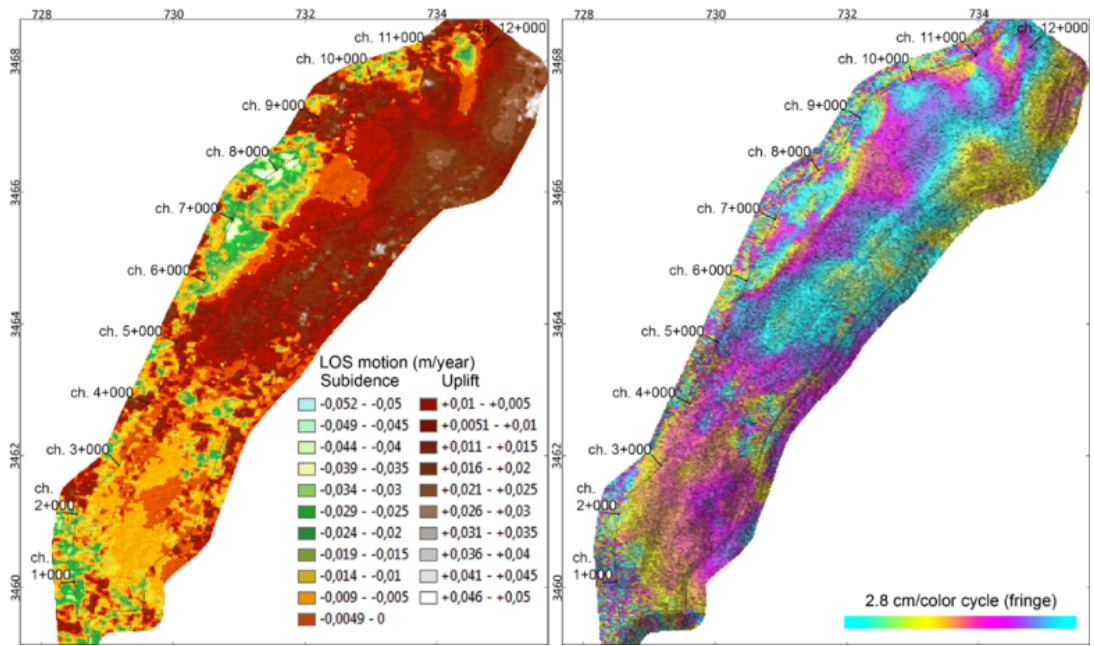

Figure 7. Motion map (left) and filtered interferogram (right) for the period 1995-07-29 to 1996-07-14 (351 days). Both images show the same information but through a classification, on the one hand, and through continuous fringes, on the other hand. Comparison between the two images allows the readers to appreciate the added value of the two sources of information. Like DEMs, motion data can be presented by mixing an hillshade representation that emphasises particular directions and slopes with a particular classification color palette. It allows an intuitive understanding of the uplift (dark brown-white) and subsidence (green) areas. On the right side, fringes reveal the continuity of the deformation fields and their interconnections. Both are usefull to catch the various dynamics.

\subsection{Detection of ground displacements before and after impoundment (starting operation stage)}

Fig. 8, left side, shows the ground motions from 1995-12-17 to 1997-10-12, i.e. during the building phase. The dike area is strongly affected by the lack of coherence leading to incomplete fringe pattern and the impossibility to generate a realistic displacement map like in Fig. 7, left. Inside SP-0A, coherence was well preserved and allowed the detection of uplift and subsidence areas. The patterns are consistent with the ones visible in Fig. 6 and 8. The most conspicuous extended from $11+000$ to $12+000$ and from $6+000$ to $8+000$. 
Once in operation (Fig. 8, right side), no information can be retrieved from the bottom anymore (white patch). The deformation fields around saltpan are the only available information to deduce the phenomena occurring below the pond and the dike. Interferogram corresponding to the period 1997-12-21 to 1999-03-21 indicates a strong subsidence in the Lynch Strait. Three fringes representing $3 \times 0.028 \mathrm{~m}$ of displacement along the line of sight can be easily delineated. This subsidence is caused by the continuous supply of sediments. Decorrelation occurs over the delta because the rate of subsidence is too important to be detected in C-band while it can be done in L-band (see Fig. 10). This external deformation field affect dike 18 from chainage $6+000$ to $7+500$.

Complex fringes are also visible between $9+500$ and $11+500$. They are localized in one of the most active zone detected in 1992-1993 (Fig. 6). They attest that underground water circulation is still active in that zone. This element is in agreement with the setting up of a jetty at 10+600 to seal sinkholes at the bottom of SP-0A.
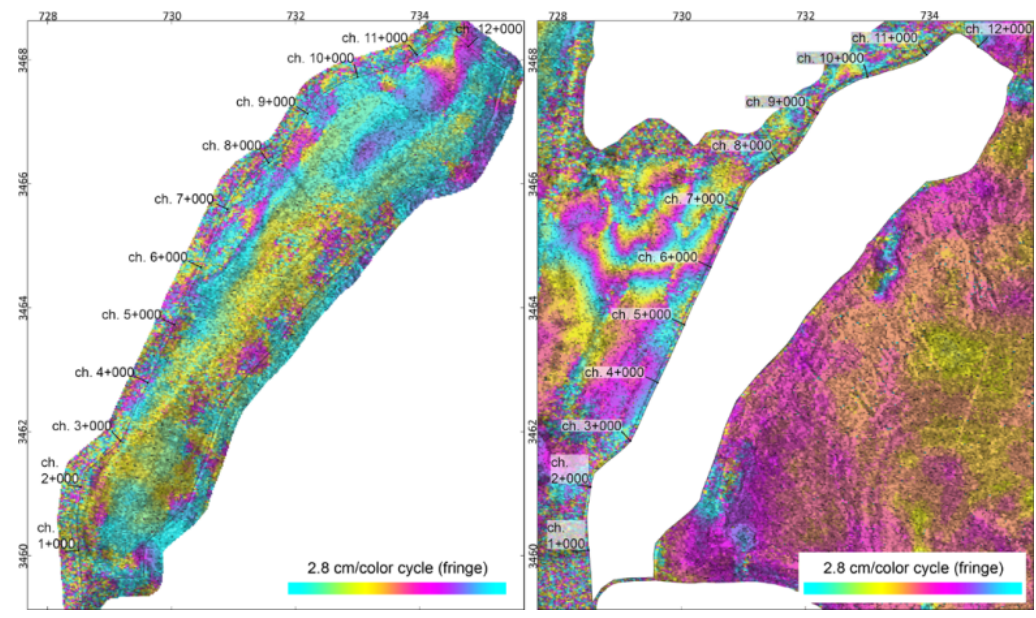

Figure 8. Left, filtered interferogram showing ground deformations recorded from 1995-12-17 to 1997-10-12 (665 days). The very short baseline of only $6 \mathrm{~m}$ allowed a clear delineation of the deformations where interferometric coherence was preserved. Obviously, during building stage, human activities modify the original distribution of the scatters on the ground. On the right, once filled, the deformations affecting the bottom become inacessible. The pair 1997-12-21 to 1999-03-21 (455 days) provided the deformation fields with a great precision and accuracy owing to the $18 \mathrm{~m}$ perpendicular baseline.

\subsection{Detection of ground displacements during repairs}

In 2001, sinkholes strongly affected the stability of dike 18. Saltpan Sp-0A was progressively emptied to raise the safety factor. As a result, a wide part of the bottom became again accessible to study the ground deformations with radar interferometry. Fig. 9 shows two informative inferograms. Comparison with Fig. 7-9 indicates many similarities. For example, both interferograms show an important subsidence between chainage $11+000$ and 12+000. 
In the southern part, from chainage $0+000$ to $2+000$, the deformations of the bottom in relation with seepage coming from SP-01 are always present. Subsidence and uplifted zones are in geographical agreement with the sinkholes and artesian springs observed over contemporary visible images.

In terms of displacement fringes, a clear contrast exists between the Lisan foreshore (now the bottom of SP-0A) and the Lynch Strait. This can be the result of water circulation below the platform caused by Wadi Araba supply. These complex deformation fields are affecting dike 18 over most of its length. Lynch Strait is a no-man's land between Israel and Jordan. There is no vegetation or activity and the area is flat. Therefore, the interferograms are showing with lots of details the ground movements. The recorded losses of coherence correspond to the presence of surface water (Wadi Araba, artesian water basins), or to areas where the speed of subsidence is too high to maintain coherence in $C$ band. For example, this is the case of the Wadi Araba delta.
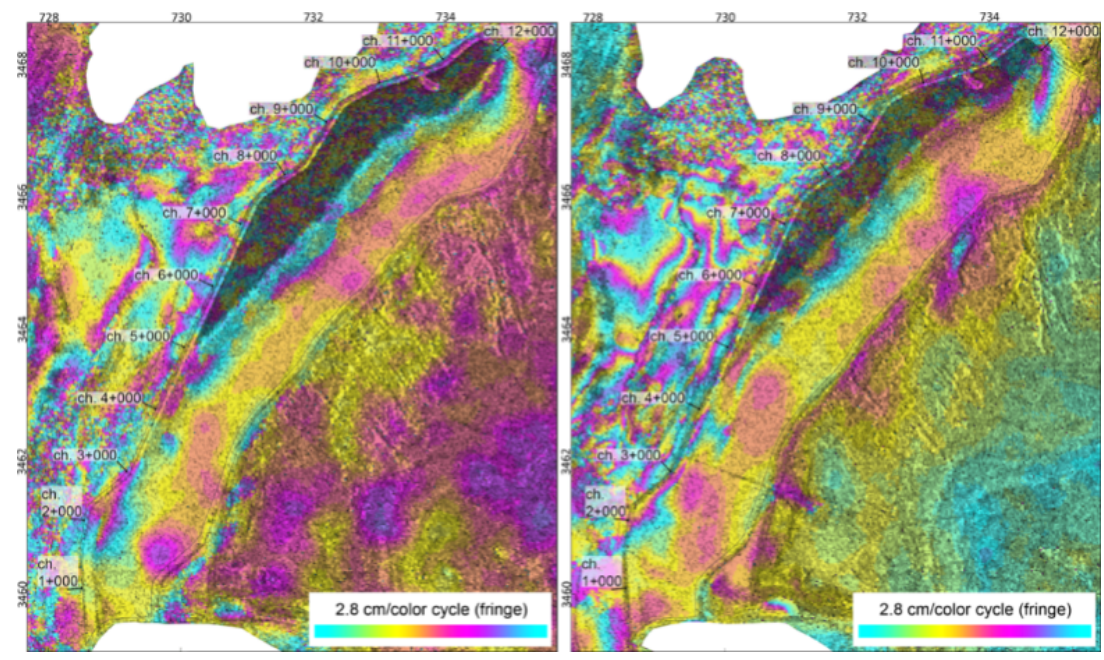

Figure 9. Left, filtered interferogram showing the deformation fields from 2004-06-27 to 2004-11-14 (140 days) with a perpendicular baseline of $37 \mathrm{~m}$ leading to an altitude of ambiguity of $249 \mathrm{~m}$. On the right, ground movements recorded between 2005-08-21 and 2006-03-19 (210 days) with a perpendicular baseline of $16 \mathrm{~m}$ and an altitude of ambiguity of $571 \mathrm{~m}$. Deformations inside SP-OA are quite similar and in agreement with the deformations recorded more than 10 years before.

\subsection{Detection of ground displacements after repairs}

Interferogram displayed in Fig. 10 seems essentially devoid of major displacements by comparison to the previous examples showing intricated fringe patterns. Two factors contribute to this appreciation. The very short period of observation (46 days) does not allow the necessary time to contrast uplift and subsidence. Secondly, L-band systems are four times less sensitive than C-band $(2.8 \mathrm{~cm}$ versus $11.8 \mathrm{~cm})$. This apparent weakness can be an advantage. 
For example, L-band allows detection in place affected by movements too rapid to preserve coherence in C-band. Comparison with Fig. 9 shows how noisy areas in the Envisat data (e.g. delta) are correctly imaged with ALOS information.

At a closer inspection, all along dike 18, some tiny deformation fields are visible. Their geographical extensions fit with ground motions previously recorded with ERS and Envisat. From Fig. 10, dike 18 can be divided into different zones based on the relative displacement between each sections: $0+000$ to 1+000 : uplift; 1+000 to 2+200 : important subsidence caused by the underground water flux coming from SP-01; $2+200$ to $4+000$ : uplift; $4+000$ to $6+600$ : subsidence; $6+600$ to $8+500$ : strong subsidence; $8+500$ to 9500 : subsidence; $9+500$ to $11+00$ : important uplift; $11+000$ to $11+700$ : subsidence.

The color cycle represents $11.8 \mathrm{~cm}$ of displacement along the line of sight recorded in 46 days. Two places have recorded a full cycle: UTM coord. 730-3468 and 728-3460. The zone located at 728-3460, outside SP-0A, is in the extension of the sinkholes lineament that appeared in 1992. Its zigzagging shape displays directions similar the the ones of the sinkholes lineament too. One as to note that in these two places, the mean velocity is about $90 \mathrm{~cm}$ per year. About 15 years before, the rates ranged from 10 to $15 \mathrm{~cm}$ per year. The difference in intensity could be explained by the always increasing head difference between the Dead Sea level and the surrounding water tables leading to a growth in the underground water discharge.

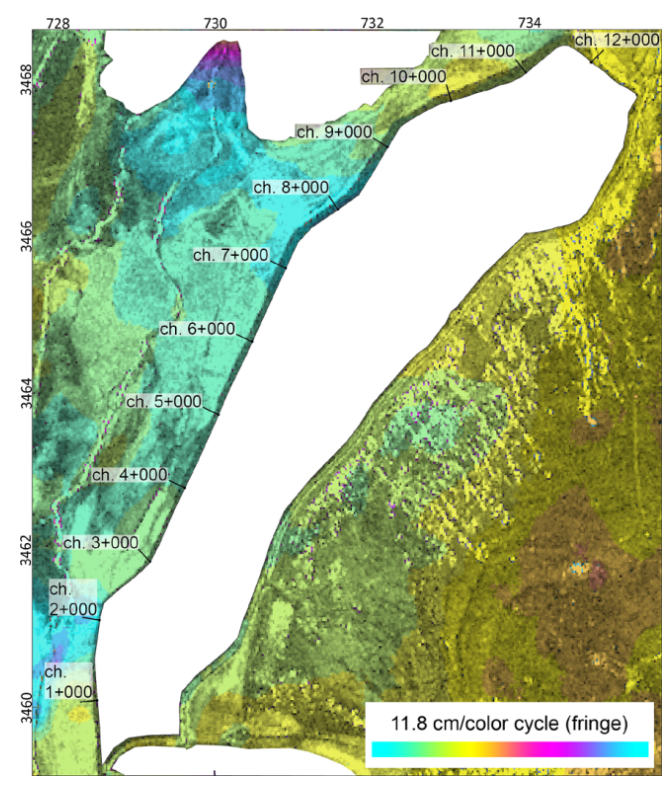

Figure 10. ALOS palsar filtered interferogram showing ground deformations recorded from 2008-04-01 to 2008-05-17 (46 days). The short baseline of $41 \mathrm{~m}$ leads to an altitude of ambiguity of $1551 \mathrm{~m}$. The image image is therefore a "true" differential interferogram. Because of L-band, some deformation fields appear clearer than with Cband in the most active zones such as the delta of wadi Araba. 


\subsection{Detection of ground displacements during operation}

Since 2007, the new high-resolution radar sensors allow a much more detailed analysis of surface displacements. Cosmo-SkyMed images, in standard mode, have a resolution between 2-3 meters, i.e. about 10 times better compared to ERS and Envisat images.

As an illustration, Fig. 11 shows the situation prevailling in the southern part of the SP-0A basin during the first half of 2012. On the right side, owing to its "coastal" (400-450 nm) spectral band, very high resolution Worldview-2 image enable the visualization of the Lisan foreshore through some meters of brine. Color changes correspond to subtle variations in the bathymetry."Topographic anomalies" such as dark circles can be detected. They are either sinkholes or artesian springs already detected at least five years earlier, when that part of SP-0A was dried up for dike repairs. In particular, a circle $300 \mathrm{~m}$ in diameter appears close to dike 18 . Other circular structures occupy the bottom of an ESE-WNW oriented "valley".

Landsat images dating back to 1984 clearly show this longitudinal "corridor" as a dark polygon surrounded by bright sediments like those of the Lisan Peninsula. The context indicates that the difference in color results from a variation of moisture. Landsat data acquired from 1984 to 1992 also revealed that dike SP-01 was affected by seepage phenomena.

Based on these observations, this structure could be a former backfilled valley reactivated after the setting-up of evaporation ponds in the former southern shallow sub-basin. The number and size of the circular structures are indicators of the importance of subsurface water flow.

Beyond the dike, Worldview 2 image does not provide any relevant indications at the exeption of the sinkholes and of the most apparent cracks. These elements, although important in hazard mapping, provide a rough idea of the deformation fields threatening the integrity of dike18.

The unwrapped phase computed from a pair of Cosmo-SkyMed images reveals the staggering blow generated by the groundwater entering the Lynch Strait by passing under dike 18. The deformation field is made of ripples (anticlinal and synclinal) centered on the main impact zone (chainage 1+200). The affected dike section is more than one kilometer long. The threat is extremely diffuse so that the established security measures oriented towards stabilization of cracks and sinkholes ("point-like" events) can not be efficient in this case. Fig. 11 provides an overall picture of the situation and this one could not be described as accurately with traditional techniques even with a dam over-equipped with sensors.

\subsection{Ground motions with SBAS technique}

The previous examples illustrated the richness of the filtered interferograms and the usefulness of the unwrapped phase data in the quantitative evaluation of the deformations.

Interferogram Stacking Technique had been designed for monitoring scenes characterized by a distributed scattering at a low resolution scale. SBAS consists in an analysis of multilook interferograms. The multilooking is a spatial averaging which is carried out by exploiting the hypothesis that the scattering is distributed. It allows increasing the phase signal quality and thus reliability of measurements. The SBAS technique uses only interferograms generated by choosing thresholds on the spatial and temporal baselines, and on Doppler centroid difference. 


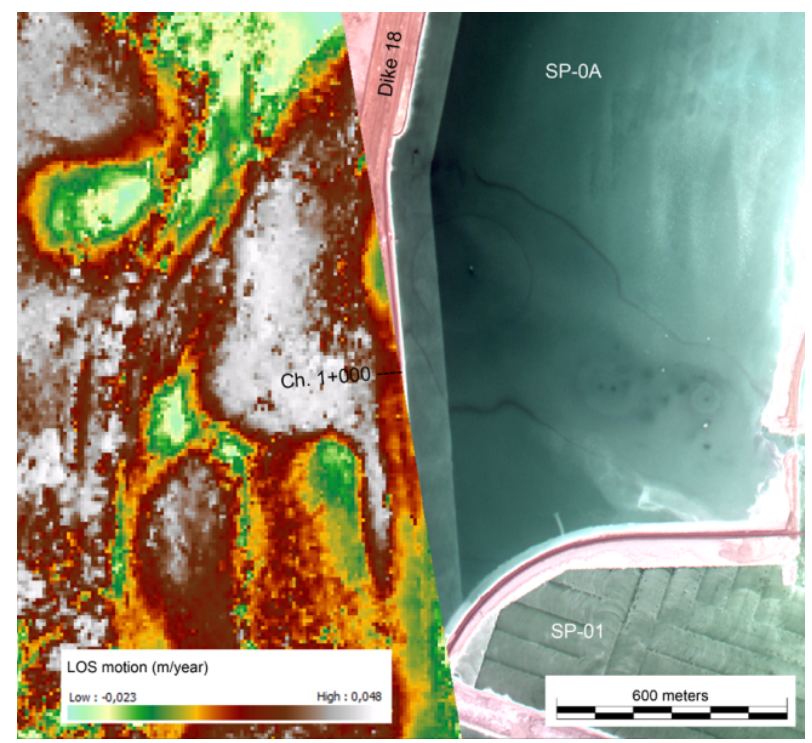

Figure 11. On the left, motion data computed from a pair of Cosmo-SkyMed images spanning from 2011-12-14 to 2012-05-06 (141 days). The deformations affecting dike 18 are related to the ongoing groundwater circulation below SP-OA. Sinkholes distribution affecting the bottom of SP-OA (right side) indicate the position of the underground stream. Worldview 2 image acquired the April $2^{\text {nd }} 2011$. Both data sets are in high resolution (about $2 \mathrm{~m}$ ).

After the unwrapping, the interferograms are inverted to retrieve the phase signal over the stack of acquisitions.

Fig. 12 shows the total displacements expressed in cm computed from a stack of 31 Envisat images (2003-07-13 to 2010-06-06). The reference is 2003-07-13. During the period of observation, SP-0A was emptied for dike repairs (2003-2006). The bottom was almost accessible to measurements with radar interferometry. About 30\% remained inaccessible, from chainage $4+000$ to $12+000$ (masked area).

Regarding ground displacements, SP-0A can be divided, from chainage $6+000$, into a northern and southern compartment. The northern part is affected by strong subsidence from chainage $6+500$ to $9+000$. The maximum is reach at $8+500$ (white pixels or no data). Another maximum is found at 10+600. The two maxima are identified in C-band from the absence of detection (white pixels) taking into account the context: no vegetation, no human activities, rapid subsidence detected in L-band (Fig. 10).

The southern compartment is characterized by three wide uplifted zones. A remarkable subsidence area is found from chainage $1+000$ to $3+000$. In this place, a wide berm (cross hatched) was build to reinforce the dike. Circular features observed in Figure 10 are also located in that zone. The results of SBAS are in agreement with the previous observations done with DInSAR approach. 

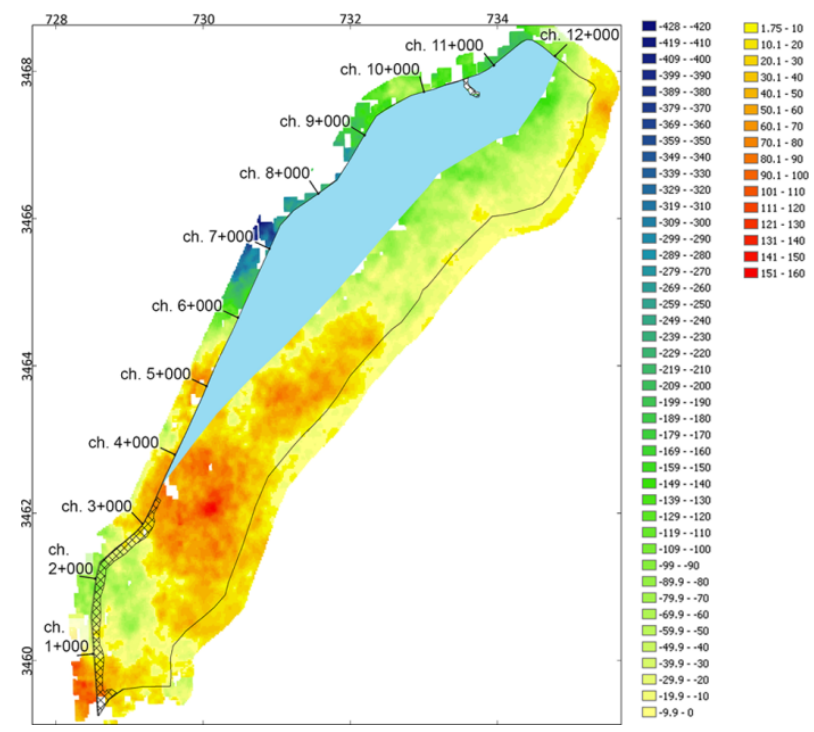

Figure 12. Total displacement in cm from 2003-01-19 to 2010-06-06 computed with SBAS technique. Blue zone corresponds to the part of the basin that remained covered by water during dike repair between 2003-2006. Cross hatched ribbon is the berm built in 1997 and designed to reinforce dike 18.

\section{Discussion}

Interferograms show the spatial extent of subsidence and uplift phenomena. At the field level or dam instruments, they seem localized, punctual, while in reality there is an important areal component, generally invisible to the eyes. It is this spatial extension that gives interest to the interferograms.

SBAS data operate a large number of interferograms. This technique allows a comparison between them and delivers a time series of ground motions that can be used to represent the dynamics of potential or actual hazards for dike 18. As an illustration, SBAS results allow a comparison with the hazards recorded during the two previous decades. Figure 13, right side column, summarizes the SBAS information in a qualitative way.

The circular features located between $1+000$ and 2+000 are in relation with subsidence phenomena. They were identified in the early 2000s owing to SPOT images and VHR acquisitions. They probably result from water ingress along a former flood channel (Fig. 11).

Those recorded from $5+500$ to $12+000$ are also in connection with subsidence. The dike segments located on the limits between uplift and subsidence are exposed to fractures where sinkholes can eventually appear. Such fractures are common in the remaining dikes 19 and 20 of SP-0B. 


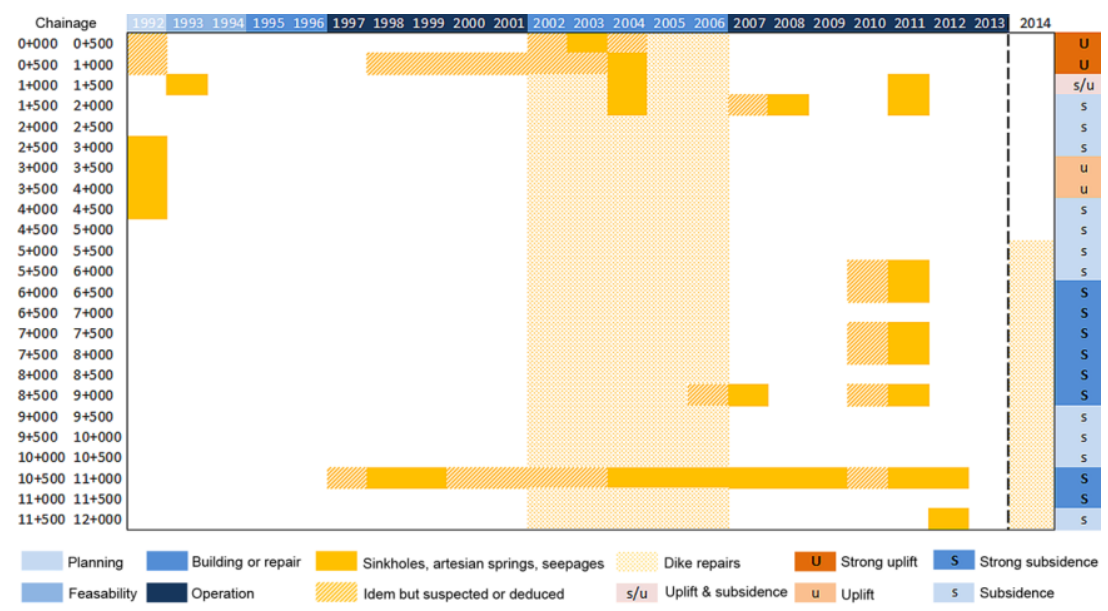

Figure 13. Comparison between sequences of hazard events along dike 18 and a qualitative assessment of the ground deformations computed from 1992 to 2010 with SBAS technique [36-38] ("SBAS" module of Sarscape software).

\section{Conclusions}

Sound interpretation of data from radar interferometry can provide the engineers in charge of dike safety with the areal component and the dynamic of hazardous phenomena, elements that are so essential to the setting up of a successful and optimally economic strategy to mitigate the damage.

The case study of dike 18 shows that an approach based on sensor densely located all along the dike provide satisfactory results when dealing with well delimited problems. The situation in the south of SP-0A, however, is different. When the hazardous events become too large, it is essential either to correlate the specific measures carried out on the dike, or use techniques such as DInSAR and SBAS which were designed for this kind of issue.

\section{Acknowledgements}

The work carried out is the fruit of a collaboration of three years with the company Sarmap SA. Special thanks go to Paolo Pasquali, Alessio Cantone and Paolo Riccardi. All results shown in this chapter have been generated with the SARscape ${ }^{\circledR}$ software package. The work of Najib Abou Karaki is supported by the Deanship of scientific research at the University of Jordan. Thanks are due to Arab Potash Company, KELLER, Sarmap, and ACES for supporting the first EAGE Workshop on Dead Sea Sinkholes (23-25.09.2012), Amman, Jordan (http:// www.eage.org/events/index.php?evp=6716\&ActiveMenu=2\&Opendivs=s3). 


\section{Author details}

Damien Closson ${ }^{1}$ and Najib Abou Karaki ${ }^{2}$

*Address all correspondence to: Damien.closson@yahoo.fr

1 Royal Military Academy, CISS Department. Brussels, Belgium

2 The University of Jordan, Environmental and Applied Geology Department. Amman, Jordan

\section{References}

[1] Salameh E and El-Naser H. Changes in the Dead Sea Level and their Impacts on the Surrounding Groundwater Bodies. Acta Hydrochemica et Hydrobiologica 2000; 28 2-33.

[2] Salameh E and El-Naser H. The Interface Configuration of the Fresh / Dead Sea Water - Theory and Measurements. Acta Hydrochemica et Hydrobiologica 2000; 28(6) 323-328.

[3] Itanar A and Reizman Y. Air Photo Survey of Sinkholes in the Dead Sea Area. Geological Survey of Israel-Current Research 2000; 12 21-24.

[4] Abelson M, Yechieli Y, Crouvi O, Baer G, Wachs D, Bein A, Shtivelman V. Evolution of the Dead Sea sinkholes. Geol Soc Am Spec Pap 2006; 40 241-253.

[5] Closson D and Abou Karaki N. Human-induced geological hazards along the Dead Sea coast. Environmental Geology 2009; 58(2) 371-380.

[6] Abou Karaki N. Synthèse et carte sismotectonique des pays de la bordure de la Méditerranée: sismicité du système de faille du Jourdain-Mer Morte. PhD thesis. Université Louis Pasteur, Strasbourg, France; 1987.

[7] Al-Zoubi A and ten Brink U.S. Salt Diapir in the Dead Sea and their Relationship to Quaternary Extensional Tectonics. Marine and Petroleum Geology 2001; 18 779-797.

[8] Closson D and Abou Karaki N. Salt karst and tectonics: sinkholes development along tension cracks between parallel strike-slip faults, Dead Sea, Jordan. Earth Surface Processes and Landforms 2009; 34(10) 1408-1421.

[9] Abelson M, Calvo R, Gabay R, Yechieli Y. Potential levels for sinkholes collapse along the western coast of the Dead Sea-Updated maps (in Hebrew, English abstract). GSI/34/2009. Jerusalem: Geological Survey of Israel; 2009. 
[10] Ezersky M G, Eppelbaum L V, Al-Zoubi A, Keydar S, Abueladas A, Akkawi E, Medvedev B. Geophysical prediction and following development sinkholes in two Dead Sea areas, Israel and Jordan. Environmental Earth Sciences 2013; 70 1463-1478.

[11] Yechieli Y, Abelson M, Bein A, Crouvi O. Sinkholes "swarns" along the Dead Sea coast: reflection of disturbance of lake and adjacent groundwater systems. GSA Bull 2006; 118(9/10) 1075-1087.

[12] Ezersky M and Frumkin A. Fault-dissolution front relation and the Dead Sea sinkhole problem. Geomorphology 2013; 201 35-44.

[13] Closson D, Abou Karaki N, Hansen H, Derauw D, Barbier C, Ozer A. Space-borne Radar Interferometric Mapping of Precursory Deformations of a Dyke CollapseDead Sea Area - Jordan. International Journal of Remote Sensing 2003; 24(4) 843-849.

[14] Landmann G, Abu Qudaira G.M, Shawabkeh K, Wrede V, Kempe S. Geochemistry of the Lisan and Damya Formations in Jordan, and implications for palaeoclimate. Quaternary International 2002; 89(1) 45-57.

[15] Smit J, Brun J-P, Fort X, Cloetingh S, Ben-Avraham Z. Salt tectonics in pull-apart basins with application to the Dead Sea Basin. Tectonophysics 2008; 449 1-16.

[16] Shimoni M, Hanssen R, Van der Meer F, Kampes B.M, Ben-Dor E. Salt diapir movements using SAR interferometry in the Lisan Peninsula, Dead Sea Rift. SPIE 4543, SAR Image Analysis, Modeling, and Techniques IV, 151 2002; doi:10.1117/12.453964.

[17] Sunna B.F. The geology of salt deposits in the Lisan Peninsula - Dead Sea: Seminar on salt in the Arab World, Ministry of Energy and Mineral Resources, Natural Resources Authorities, May 4-6, 1986, Amman, Jordan.

[18] Closson D, LaMoreaux P.E, Abou Karaki N, al-Fugha H. Karst system developed in salt layers of the Lisan Peninsula, Dead Sea, Jordan. Environmental Geology 2007; 52(1) 155-172.

[19] Knill J. Report on a Visit 8-11 January 1993 Extension West of Lisan Peninsula Sinkholes Along Access Road, The Arab Potash project, Amman, 1993. (Unpublished report)

[20] Knight D.J. Extension West of Lisan Peninsular Sinkholes along Access Road. The Arab Potash Company, DJK/A110/92235B, Amman, 1993. (Unpublished report)

[21] Al-Homoud A.S, Makinson C, Tal A.B, Penman J.G. In-situ geotechnical experimentation and stability evaluation of an instrumented $180 \mathrm{~m} \times 70 \mathrm{~m} \times 12.5 \mathrm{~m}$ fill dike constructed on laminated soft ground. Environmental Geology 1999; 39(2) 177-196.

[22] Gabriel A.K, Goldstein R.M, Zebker H.A. Mapping small elevation changes over large areas: differential radar interferometry. Journal of Geophysical Research 1989; 94 (B7) 9183-9191. 
[23] Guarnieri M, Parizzi F, Pasquali P, Prati C, Rocca F. SAR Interferometry Experiments with ERS-1. In: Proceedings of IGARSS '93, August 1993, vol. 3, Tokyo, Japan.

[24] Massonnet D, Rossi M, Carmona C, Adragna, Peltzer G, Feigl K, Rabaute T. The displacement field of the Landers earthquake mapped by radar interferometry. Nature 1993; 364 138-142.

[25] Ge L, Chang H, Ng AH-M, Rizos C. Spaceborne radar interferometry for mine subsidence monitoring in Australia. In: Proceedings Future of Mining, presented at 1st International Future Mining Conference, 19-21 November 2008, UNSW, Sydney, Australia.

[26] Tabbal M, Mansour Z. Extensive geotechnical instrumentation program to control dike raising constructed on soft clay. Jurnal Ilmiah Semesta Teknica 2009; 12(2) 147-156.

[27] Jordan Equity Research. Arab Potash Co. Dead Sea Harvest; 2003.

[28] International Centre for Settlement of Investment Disputes. Washington, D.C., Case No. ARB/08/2. In the proceedings between ATA Construction, Industrial and Traiding Company (Claimant)-and-The Hashemite Kingdom of Jordan (Respondent), May 18, 2010. https://icsid.worldbank.org/ICSID/FrontServlet?requestType=CasesRH\&actionVal=showDoc\&docId=DC1491_En\&caseId=C264 (accessed 15 July 2013).

[29] Djavid M, Mohammadi J. Comparative Risk Analysis for Reconstruction of a Partially Failed Dike System. American Society of Civil Engineers, Practice Periodical on Structural design and Construction 2011; 130-143.

[30] Arab Potash Company, Annual report 2001. www.arabpotash.com/_potash/ App_Upload/PDF/2001.pdf (accessed 15 July 2013).

[31] Arab Potash Company, Annual report 2007, 80. www.arabpotash.com/_potash/ App_Upload/pdf/2007_Annual_English.pdf (accessed 15 July 2013).

[32] Arab Potash Company, Annual report 2006. www.arabpotash.com/_potash/ App_Upload/PDF/2006English.pdf (accessed 15 July 2013)

[33] Halasah Z. Utilization of Satellite Image to Improve Solar Ponds Production. 24th AFA International Technical Fertilizers Conference and Exhibition, 22-24 November 2011, Amman, Jordan.

[34] Baer G, Schattner U, Wachs D, Sandwell D, Wdowinski S, Frydman S. The Lowest Place on Earth is Subsiding-An InSAR (Interferometric Synthetic Aperture Radar) Perspective. Geological Society of America Bulletin 2002; 114(1) 12-23.

[35] Ben-Avraham Z. Geophysical Framework of the Dead Sea: Structure and Tectonics. In: Niemi T.M, Ben-Avraham Z, Gat J. (Eds) The Dead Sea, the Lake and its Setting. Oxford University Press; 1997. p22-35.

[36] Closson D, Pasquali P, Abou Karaki N, Milisavljevic N, Hallot F, Acheroy M, Holecz F. Dead Sea Karst System Dynamics Measured with Insar PS and SBAS Techniques. 
Poster XY 383, EGU 2011. http://presentations.copernicus.org/EGU2011-1125_presentation.pdf (accessed 15 July 2013).

[37] Closson D, Abou Karaki N, Pasquali P, Riccardi P, Holecz F. Karst Dynamics Revealed by Small Baseline Subset Interferometric Technique. EAGE Workshop on Dead Sea Sinkholes - Causes, Effects \& Solutions, 23 September 2012, Amman, Jordan.

[38] Pasquali P, Riccardi P, Abou Karaki N, Closson D, Holecz F. Very High Resolution ground displacement mapping and monitoring over the Lisan Peninsula: Preliminary Results. EAGE Workshop on Dead Sea Sinkholes - Causes, Effects \& Solutions, 23 September 2012, Amman, Jordan. 
